anales de psicología / annals of psychology

2019, vol. $35, \mathrm{n}^{\circ} 1$ (january), 68-74

http://dx.doi.org/10.6018/analesps.35.1.302131
(C) Copyright 2019: Editum. Servicio de Publicaciones de la Universidad de Murcia. Murcia (Spain) ISSN print edition: 0212-9728. ISSN on line edition (http://revistas.um.es/analesps): 1695-2294.

On line edition License Creative Commons 4.0: BY-NC-ND

\title{
Sex differences in estimates of lay views about reversal motivational intelligences for self and others: A replication in Brazil
}

\author{
Félix Neto
}

Universidade do Porto (Portugal)

\begin{abstract}
Título: Diferencias de sexo en las estimaciones legas sobre inteligencias motivacionales inversas para uno mismo y para otros: una réplica en Brasil. Resumen: Esta investigación abordó las diferencias de género en inteligencias motivacionales inversas globales y creencias sobre la inteligencia autoestimadas y estimadas por otros en Brasil. La muestra comprendió a 174 estudiantes (96 mujeres y 78 hombres). Los participantes respondieron a una encuesta en la que estimaron la inteligencia motivacional de sus padres, socios y propios, y las ocho inteligencias de inversión. También evaluaron seis factores sobre la inteligencia. Los hombres evaluaron su inteligencia general más alta que las mujeres. En contraste, las mujeres proporcionaron mayor autoestimación de inteligencias del dominio "aloico" (autopromoción intelectual) y de simpatía "aloica" (inteligencia interpersonal) que los hombres. Las mujeres y los hombres no difirieron en las estimaciones de la inteligencia motivacional inversa de la pareja y parental. Los encuestados calificaron a sus padres como más inteligente que sus madres. En general, los encuestados se evaluaron a sí mismos como más inteligentes que sus padres. Los padres fueron calificados como más inteligentes que las madres en inteligencia general. Las inteligencias "telic" (intrapersonal) y conformistas fueron predictores significativos de la inteligencia general. El análisis factorial de las ocho inteligencias motivacionales inversas evidenció una estructura unidimensional. La mayoría de los encuestados no creía en las diferencias de género en inteligencia. Los resultados se discuten teniendo en cuenta la literatura existente en el campo.

Palabras clave: Brasil; Inteligencia; Padres; Parejas; Autoevaluación; Dife-
\end{abstract} rencias de género.

\section{Introduction}

This study examines self-estimated intelligence (SEI) which represents currently an issue of prominent interest (Furnham \& Shagabutdinova, 2012; Kaufman, 2012). For instance, SEI has self-fulfilling effects towards the examination performance (Chamorro-Premuzic, Furnham, \& Moutafi, 2004).

\section{Self-estimated intelligence}

SEI is defined "as people's estimates of their own cognitive abilities on a standard IQ scale in comparison to the overall population" (Szymanowicz \& Furnham, 2011, p. 493). Diverse cross-cultural works of SEI have been conducted. For example, investigations have been conducted in Africa (Angola, Guinea-Bissau, Namibia, South Africa, Uganda, Zambia, and Zimbabwe), North America (the United States), Asia (China, Hong Kong, Japan, Macao, Malaysia, Singapore, East Timor), Europe (Belgium, Germany, Portugal, United Kingdom), and Middle East (Egypt, Iran,

* Correspondence address [Dirección para correspondencia]: Félix Neto, Faculdade de Psicologia e de Ciências da Educação, Universidade do Porto, Rua Alfredo Allen, 4200-135, Porto (Portugal).

E-mail: fneto@fpce.up.pt

(Article received: 9-8-2017; revised: 7-12-2017; accepted: 21-8-2018)
Abstract: This research approached gender differences in self- and otherestimated overall, reversal motivational intelligences and beliefs about intelligence in Brazil. The sample comprised 174 (96 women and 78 men) students. Participants answered a survey where they estimated their parents', partners' and own overall and the eight reversal motivational intelligences. They also evaluated six factors about intelligence. Men assessed their overall intelligence higher than women. By contrast, women provided greater self-estimates of alloic mastery and alloic sympathy intelligences than men. Women and men did not differ in estimates of partner and of parental reversal motivational intelligences. Respondents rated their father as more intelligent than their mothers. In general, respondents evaluated themselves as more intelligent than their parents. Fathers have been rated as more intelligent than mothers on overall intelligence. Telic and conformist intelligences were significant predictors of overall intelligence. Factor analysis of the eight reversal motivational intelligences evidenced a unidimensional structure. Most of respondents did not believe in gender differences in intelligence. The results are discussed taking into account the extant literature in the field.

Keywords: Brazil; Intelligence; Parents; Partners; Self-assessment; Gender differences.

Lebanon) (Syzmanowicz \& Furnham, 2011). Globally, these investigations have displayed both gender and cultural differences, but few interactions between the two (Furnham, 2001).

Some of the most important investigation about SEI has been: gender differences in estimation of global intelligence and on specific self-estimates of intelligence (Byrd \& Stacey, 1993; Szymanowicz \& Furnham, 2013); intergenerational differences in SEI (Swami, Furnham, \& Kannan, 2006; Pérez, González, \& Beltrán, 2010; Neto \& Furnham, 2011); crosscultural differences in SEI (Furnham \& Akande, 2004; Neto, Furnham, \& Paz, 2007; Neto, Pinto, Mullet, \& Furnham, 2016); the relation between SEI and personality traits (Furnham, Zhang, \& Chamorro-Premuzic, 2006; Neto, Mullet, \& Furnham, 2016); and correlations between SEI and psychometrically measured IQ are positive and significant, but modest (Furnham, 2001), suggesting that self-estimated intelligence may be impacted by other features (ChamorroPremuzic \& Furnham, 2005).

\section{Reversal motivational intelligences}

Current work examines lay estimates of motivational intelligences within reversal theory (Apter, 2001) which is "a dynamic view of human functioning" arguing that "metamotivational states, and the values that they represent, go in 
pairs of opposites, so that one type of change would involve switching between these opposites" (Giraudeau, Chasseigne, Apter, \& Mullet, 2007, p. 171). Apter's metamotivational theory has been applied to study phenomena, such as addictions, smoking, risk-taking, creativity (Apter, 2001).

Giradeaux et al. (2007) examined the structural conception of intelligence using the motivational style of reversal theory. They demonstrated eight factors likely to be interpreted within this theory. For those scholars three factors have already been evidenced in Western research: negativistic (interest in ability to deal novelty), autic mastery (everyday competence), and conformist (verbal competence). Three other factors have also been evidenced in Eastern research: telic (intrapersonal intelligence), alloic mastery (intellectual self-promotion), and alloic sympathy (interpersonal intelligence). The two remaining factors - autic sympathy (positive evaluation of him/herself) and paratelic (ability to enjoy life) - were not yet marked within implicit intelligence.

The first work examining lay estimates of conceptions of motivational intelligences using this eight dimensional structure (Girardeau et al., 2007) was conducted among adolescents attending secondary schools (Neto, Mullet, \& Furnham, 2009). That investigation examined the relationship between gender and self-estimation of lay views about intelligence for self and parents. The gender effect vanished when youths assessed their parents in agreement with previous results (Rammstedt \& Rammsayer, 2000). Furthermore, the greater participants assessed their own eight reverse motivational intelligences, the greater they assessed all reversal motivational intelligences of their parents. Recently, correlates (Neto et al., 2016) and cross-cultural comparisons (Neto et al., in press) of lay views on reversal motivational intelligences for self and others have been studied.

\section{The present study}

Current study extends extant research by investigating self, partner, and parental estimates of intelligence among Brazilian people. At the best of our knowledge no previous research has analysed SEI in Brazil, and this is the first research using reversal motivational intelligences in Latin America.

The first objective of this research is to analyse whether there are gender differences in global and reversal motivational intelligences. Past research showed that gender differences in global intelligence are minor (Colom et al., 2000); however, men tend to estimate their global intelligence greater than women. Cross-cultural works documented that these gender differences are found in every continents (von Stumm et al., 2009). For example, males displayed higher self-estimate of their global intelligence than females in Angola and East Timor (Neto, in press).

Studies of SEI, such as those suggested by Gardner (1999) or Sternberg (1997) tended to show gender differences only in terms of mathematical/numerical and spatial intelligence (Szymanowicz \& Furnham, 2011). Men tended to evidence greater estimates in the two self-assessed intelligences than women. These consistent findings on gender differences have been termed a male hubris-female humility effect in SEI (Furnham, Fong, \& Martin, 1999). In the Portuguese cultural context, adolescents (Neto et al., 2009) as well as adults (Neto et al., 2016) showed gender differences in autic sympathy. Men assessed their autic sympathy intelligence higher than did women. Furthermore, adolescents showed sex differences in alloic sympathy. Girls rated themselves greater on alloic sympathy intelligence than boys.

Gender differences are not limited to self-estimate of intelligence. Gender differences have also been documented in estimates of intelligence of close others. For example, past investigation has shown that, on average, grandmothers, mothers, daughters, and sisters are estimated as less intelligent than their male counterparts (Byrd \& Stacey, 1993; Furnham, 2001; Neto \& Furnham, 2011). However, gender differences in estimates seem to be more strongly endorsed for self than for others. Moreover, generational differences were found. Each generation believes to become more intelligent than the previous generation (the Flynn effect).

Another objective of this work is to analyse which reversal motivational intelligences are considered the strongest predictors of global intelligence, yielding insights into what lay people believe constitutes intelligence. Diverse works using self-estimates of Gardner multiple intelligences evidenced that mathematical, spatial and verbal intelligences were the best predictors of self-estimated global intelligence (e.g., Furnham, 2001). Conformist, negativistic, and autic mastery emerged as significant predictors of the global evaluation of intelligence for the self and their parents among Portuguese adolescents (Neto et al., 2009) and for the self among Portuguese adults (Neto et al., 2016).

Another objective of this work is to analyse the structure of the eight reversal motivational intelligences. Previous studies conducted in Angola, East Timor, and Portugal evidenced one factor (Neto et al., 2009; 2016; in press). This finding is not in line with a great number of past studies which tend to evidence either two or three factors depending on which multiple intelligences were examined (e.g., Furnham, 2004).

Therefore, this research examines gender differences in self-estimated IQ and estimates of partners' and parents' IQ among Brazilian people. In light of past findings five hypotheses were tested:

Hypothesis 1: It was hypothesized that there would be gender differences in self-rated overall, autic sympathy and alloic sympathy intelligences, with men endorsing greater overall and autic sympathy self-estimates than women, and women endorsing greater alloic sympathy self-estimate than men.

Hypothesis 2: Respondents would estimate their fathers as more overall intelligent than their mothers.

Hypothesis 3: Respondents would rate themselves higher on reversal motivational intelligences than their parents. 
Hypothesis 4: The best predictors of overall (g) IQ would be conformist, negativistic, and autic mastery intelligences.

Hypothesis 5: Factor analysis of the eight reversal motivational intelligences would display one factor solution.

Other analyses were planned, yet no specific hypotheses were advanced. In this line it was explored the relationship between IQ test beliefs and experience, and self-estimated intelligences. Past work has demonstrated that they are linked (Furnham, Rakow, \& Mak, 2002; Furnham, 2005).

\section{Method}

\section{Participants}

The sample consisted of 174 students (96 females and 78 males) from Brasilia University, Brazil. The mean age of the Brazilian students was 24.88 years $(S D=4.45)$. All participants spoke Portuguese as their mother tongue. Participants were social sciences students.

\section{Measures}

Self-Estimated Intelligence. The questionnaire has already been designed (Neto et al., 2009), grounded on past research in the domain (Furnham, 2001; Neto \& Furnham, 2006). A normal IQ distribution, described in detail, was presented to the respondents. Subsequently, respondents were shown a grid with nine rows and four columns. The first row was labelled "Overall Intelligence" and the remaining eight taken from Girardeau et al.'s (2007) list of reversal theory motivational intelligences (see Table 1). The columns were labelled "You", "Your Partner", "Your Father", and "Your Mother". Hence, each participant was requested to make 36 IQ estimates. A higher score on the estimates indicates a higher estimated intelligence.

Beliefs about intelligence. These consisted of 6 questions (see Table 5) used in diverse works in this domain (e. g., Furnham, Rakow, \& Mak, 2005; Neto, Ruiz, \& Furnham, 2008).

\section{Procedure}

The Portuguese version of the questionnaire was administered (Neto et al., 2009). Participants answered the questionnaire in class groups of 12 to 20 at the university. After consent obtained, participants completed the questionnaire. There was a $100 \%$ response rate. Respondents were all appropriately debriefed.

\section{Data analysis}

A multivariate analysis of variance (MANOVA) was conducted to provide whether there were significant gender differences in self-estimates of overall and reversal motivational intelligences. The same MANOVA was also perfor- med for estimates of partner, paternal, and maternal intelligences.

$T$-tests (with Benferroni corrections) were conducted to analyse generational and self-partner differences in estimates of intelligence. Four multiple regression analyses were conducted to examine the best predictors of overall intelligence estimates. Factor analysis (principal component) was conducted for the 8 ratings of the self to analyse the structure of reversal motivational intelligences. A series of chi-squares were performed on the six beliefs about intelligence to show whether there were gender differences.

\section{Results}

\section{Gender differences}

Table 1 shows the estimated scores for men and women on all 36 estimates. A multivariate analysis of variance (MANOVA) was conducted to provide whether there were significant gender differences in self-estimates of overall and reversal motivational intelligences. The MANOVA yielded a significant effect of gender, Wilks $\lambda=.89[F(9,163)=2.33$, $p$ $\left.<.05, \eta_{p}^{2}=.11\right]$, with men showing greater self-estimates than women on overall intelligence, $[F(1,173)=4.60, p<$ $\left..05, \eta_{p}^{2}=.03\right]$. By contrast, women provided higher selfestimates of alloic mastery, $\left[F(1,173)=3.91, p<.05, \eta_{p}^{2}=\right.$ $.02]$, and alloic sympathy, $\left[F(1,173)=7.31, p<.01, \eta_{p}^{2}=\right.$ $.04]$.

The same MANOVA was also performed for estimates of partner intelligence, but no significant effect of gender was observed, Wilks $\lambda=.95\left[F(9,161)=.95, p>.05, \eta_{p}^{2}=\right.$ .05]. A MANOVA of estimates of paternal, Wilks $\lambda=.92$ $\left[F(9,161)=1.57, p>.05, \eta_{p}^{2}=.08\right]$, and maternal intelligences, Wilks $\lambda=.94\left[F(9,163)=1.16, p>.05, \eta_{p}{ }^{2}=.06\right]$, likewise displayed no significant effect of gender.

\section{Generational and self-partner differences}

Various $t$-tests (with Bonferroni corrections) were conducted to analyse generational and self-partner differences in estimates of intelligence. Results are shown in Table 2. In terms of self-partner ratings, respondents evaluated their partners as being more intelligent than themselves on overall, and conformist intelligences. In terms of parental ratings, respondents evaluated themselves as more intelligent than parents on paratelic, conformist, negativistic, autic mastery, autic sympathy, and alloic mastery intelligences. They also gave themselves higher scores than their mothers on overall and telic intelligences. They also gave themselves higher scores than their fathers on alloic sympathy intelligence. Finally, respondents gave their higher scores than their mothers on overall intelligence. Mothers were rated as more intelligent than their fathers on alloic sympathy intelligence. 
Table 1. Gender differences in estimates of self, partner and parental intelligence.

\begin{tabular}{|c|c|c|c|c|c|c|c|c|c|}
\hline \multirow{2}{*}{ Intelligence type } & \multirow[t]{2}{*}{ Sex } & \multicolumn{2}{|c|}{ You } & \multicolumn{2}{|c|}{ Your partner } & \multicolumn{2}{|c|}{ Your father } & \multicolumn{2}{|c|}{ Your mother } \\
\hline & & M & SD & M & SD & M & SD & M & SD \\
\hline \multirow[t]{2}{*}{ Overall } & Men & 105.26 & 12.10 & 106.32 & 15.15 & 103.51 & 17.36 & 98.85 & 18.05 \\
\hline & Women & 101.41 & 13.07 & 106.80 & 13.62 & 99.04 & 15.21 & 94.47 & 14.85 \\
\hline \multicolumn{10}{|c|}{ Telic: to be able to display life goals, to pursue and to achieve them } \\
\hline & Men & 107.21 & 16.79 & 109.87 & 19.22 & 103.51 & 18.83 & 101.73 & 19.19 \\
\hline & Women & 107.45 & 16.69 & 110.42 & 17.92 & 101.49 & 20.72 & 103.37 & 20.03 \\
\hline \multicolumn{10}{|c|}{ Paratelic: to be able to enjoy a good life } \\
\hline & Men & 110.13 & 17.62 & 109.87 & 19.22 & 98.25 & 18.04 & 100.64 & 18.43 \\
\hline & Women & 111.77 & 19.63 & 111.42 & 17.89 & 103.24 & 17.90 & 100.79 & 20.57 \\
\hline \multicolumn{10}{|c|}{ Conformist: to be able to know and to apply seriously basic intellectual rules - orthography, vocabulary, algebra } \\
\hline & Men & 104.09 & 13.47 & 107.89 & 15.96 & 100.19 & 20.72 & 98.45 & 20.61 \\
\hline & Women & 105.16 & 17.11 & 108.21 & 16.04 & 96.65 & 19.45 & 93.84 & 20.23 \\
\hline \multicolumn{10}{|c|}{ Negativistic: to be capable of creative originality - new ideas, new vision } \\
\hline & Men & 107.60 & 17.48 & 109.87 & 17.07 & 100.78 & 19.60 & 99.04 & 17.32 \\
\hline & Women & 106.94 & 18.27 & 106.32 & 16.46 & 98.54 & 17.61 & 97.47 & 20.48 \\
\hline \multicolumn{10}{|c|}{ Autic mastery: to have a good opinion of him/herself, to evaluate positively him/herself } \\
\hline & Men & 108.96 & 18.89 & 107.30 & 17.92 & 102.14 & 18.80 & 101.92 & 19.99 \\
\hline & Women & 107.86 & 16.36 & 107.42 & 17.35 & 101.12 & 17.90 & 100.16 & 18.88 \\
\hline \multicolumn{10}{|c|}{ Autic sympathy: to have a good opinion of him/herself, to evaluate positively him/herself } \\
\hline & Men & 108.38 & 17.46 & 107.50 & 17.58 & 102.53 & 14.68 & 100.45 & 17.71 \\
\hline & Women & 108.28 & 18.71 & 110.74 & 16.76 & 102.93 & 18.35 & 99.37 & 17.22 \\
\hline \multicolumn{10}{|c|}{ Alloic mastery: to know how to learn respect for others, to know how to defend ones point of view } \\
\hline & Men & 108.38 & 18.93 & 109.47 & 17.47 & 103.31 & 18.95 & 102.69 & 18.99 \\
\hline & Women & 113.96 & 17.95 & 11.26 & 18.29 & 104.95 & 21.03 & 104.47 & 19.47 \\
\hline \multicolumn{10}{|c|}{ Alloic sympathy: to be able to love and to be generous towards others } \\
\hline & Men & 110.52 & 18.22 & 111.84 & 17.55 & 104.09 & 21.16 & 113.08 & 22.07 \\
\hline & Women & 117.71 & 16.67 & 115.79 & 17.96 & 108.78 & 19.97 & 114.79 & 19.14 \\
\hline
\end{tabular}

Table 2. Paired $t$-Tests Comparing Mean Overall Estimates of Self and Others Com

\begin{tabular}{|c|c|c|c|c|c|c|c|c|c|}
\hline . & & & & & Comparison & Mean & Scores & $\mathrm{Df}$ & $\mathrm{t}$ \\
\hline Comparison & Mean & Scores & Df & $\mathrm{t}$ & Father versus Mother & 99.5 & 98.06 & 169 & 1.13 \\
\hline Overall intelligence & & & & & Autic mastery & & & & \\
\hline Self versus Partner & 103.25 & 106.58 & 170 & $-3.25^{* *}$ & Self versus Partner & 108.45 & 107.37 & 170 & .72 \\
\hline Self versus Father & 103.16 & 101.05 & 170 & 1.60 & Self versus Father & 108.60 & 101.58 & 170 & $4.30 * * *$ \\
\hline Self versus Mother & 103.29 & 96.45 & 172 & $5.67^{* * *}$ & Self versus Mother & 108.44 & 100.95 & 172 & $4.70^{* * *}$ \\
\hline Father versus Mother & 101.15 & 96.47 & 169 & $3.64^{* * *}$ & Father versus Mother & 101.68 & 100.88 & 169 & .57 \\
\hline Telic & & & & & Autic sympathy & & & & \\
\hline Self versus Partner & 107.25 & 110.18 & 170 & -2.06 & Self versus Partner & 108.25 & 109.30 & 170 & -.70 \\
\hline Self versus Father & 106.96 & 102.40 & 170 & 2.45 & Self versus Father & 108.33 & 102.75 & 170 & $3.34 * *$ \\
\hline Self versus Mother & 107.25 & 102.63 & 172 & $2.78^{* *}$ & Self versus Mother & 108.24 & 99.86 & 172 & $5.09 * * *$ \\
\hline Father versus Mother & 102.41 & 103.32 & 169 & .06 & Father versus Mother & 102.68 & 99.86 & 169 & 2.13 \\
\hline Paratelic & & & & & Alloic mastery & & & & \\
\hline Self versus Partner & 111.08 & 110.73 & 170 & .26 & Self versus Partner & 111.52 & 111.58 & 170 & -.05 \\
\hline Self versus Father & 110.96 & 100.99 & 170 & $6.23^{* * *}$ & Self versus Father & 111.43 & 104.21 & 170 & $4.02 * * *$ \\
\hline Self versus Mother & 111.30 & 100.72 & 172 & $6.45^{* * *}$ & Self versus Mother & 111.47 & 103.68 & 172 & $4.34 * * *$ \\
\hline Father versus Mother & 101.00 & 100.47 & 169 & .41 & Father versus Mother & 104.15 & 103.62 & 169 & .37 \\
\hline Conformist & & & & & Alloic sympathy & & & & \\
\hline Self versus Partner & 104.56 & 108.07 & 170 & $-2.56^{*}$ & Self versus Partner & 114.69 & 114.03 & 170 & .51 \\
\hline Self versus Father & 104.65 & 98.25 & 170 & $4.10^{* * *}$ & Self versus Father & 114.50 & 106.62 & 169 & $4.99 * * *$ \\
\hline Self versus Mother & 104.77 & 95.92 & 172 & $5.21 * * *$ & Self versus Mother & 114.59 & 113.84 & 171 & .49 \\
\hline Father versus Mother & 98.24 & 96.02 & 170 & 1.43 & Father versus Mother & 106.79 & 113.91 & 169 & $-.4 .93^{* * *}$ \\
\hline Negativistic & & & & & ${ }^{*} p<.05 ; * * p<.01 ; * * * p$ & 001. & & & \\
\hline $\begin{array}{l}\text { Self versus Partner } \\
\text { Self versus Father }\end{array}$ & $\begin{array}{l}106.67 \\
106.49\end{array}$ & $\begin{array}{c}107.89 \\
99.56\end{array}$ & $\begin{array}{l}170 \\
170\end{array}$ & $\begin{array}{c}-.91 \\
4.49 * * *\end{array}$ & & & & & \\
\hline Self versus Mother & 106.59 & 98.18 & 172 & $5.47 * * *$ & & & & & \\
\hline
\end{tabular}




\section{Reversal motivational intelligence predictors of ove- rall intelligence}

Next we examined which of the diverse reversal motivational intelligences were the strongest predictors of overall intelligence estimates. Four multiple regression analyses were conducted. The overall intelligence estimates for self, partner, father and mother were the criterion variables, and the Apter's eight reversal motivational intelligences were the predictor variables (see Table 3).

Self-estimates. The regression for self-estimates was significant, $F(8,172)=9.42, p<.001, \mathrm{R}^{2}=.32$, and paratelic $(\beta=$ $.20, t=2.22)$, conformist $(\beta=.16, t=2.18)$, negativist $(\beta=$ $.16, t=2.06)$, and alloic mastery $(\beta=.20, t=2.07)$ intelligences emerged as significant predictors.
Partner estimates. The regression for partner's estimates was also significant, $F(8,170)=25.50, p<.001, \mathrm{R}^{2}=.56$, and telic $(\beta=.39, t=5.57)$, paratelic $(\beta=.15, t=2.31)$, conformist $(\beta=.26, t=3.66)$, and negativistic $(\beta=.16, t=2.33)$ intelligences emerged as significant predictors.

Father estimates. The regression for paternal estimates was significant, $F(8,170)=25.55, p<.001, \mathrm{R}^{2}=.53$, and telic $(\beta$ $=.24, t=3.23)$, conformist $(\beta=.44, t=6.06)$, and autic mastery $(\beta=.20, t=2.61)$ intelligences emerged as significant predictors.

Mother estimates. The regression for maternal estimates was also significant, $F(8,172)=19.93, p<.001, \mathrm{R}^{2}=.49$, and telic $(\beta=.28, t=3.67)$, and conformist $(\beta=.42, t=$ $5.33)$ intelligences emerged as significant predictors.

Table 3. Regressions of the eight reversal multiple intelligences onto the overall estimate of intelligence.

\begin{tabular}{|c|c|c|c|c|c|c|c|c|}
\hline & \multicolumn{2}{|c|}{ Self } & \multicolumn{2}{|c|}{ Partner } & \multicolumn{2}{|c|}{ Father } & \multicolumn{2}{|c|}{ Mother } \\
\hline & $\beta$ & $t$ & $\beta$ & $t$ & $\beta$ & $t$ & $\beta$ & $t$ \\
\hline Telic & .07 & .85 & .39 & $5.57 * * *$ & .24 & $3.23 * *$ & .28 & $3.67 * * *$ \\
\hline Paratelic & .20 & $2.22^{*}$ & .15 & $2.31 *$ & -.03 & -.43 & .05 & .64 \\
\hline Conformist & .16 & $2.18^{*}$ & .26 & $3.66^{* * *}$ & .44 & $6.06^{* * *}$ & .42 & $5.33 * * *$ \\
\hline Negativist & .16 & $2.06^{*}$ & .16 & $2.33 *$ & -.02 & -.28 & .08 & 1.11 \\
\hline Autic mastery & .12 & 1.49 & .01 & .08 & .20 & $2.61 *$ & .14 & 1.69 \\
\hline Autic sympathy & .01 & .05 & -.01 & -.05 & -.03 & -.32 & -.15 & -1.75 \\
\hline Alloic mastery & .20 & $2.07^{*}$ & .04 & .49 & .09 & 1.02 & .06 & .76 \\
\hline Alloic sympathy & -.17 & -1.97 & -.10 & -1.42 & -.09 & -1.29 & -.12 & -1.69 \\
\hline $\mathrm{F}$ & $9.42^{* * *}$ & & $25.50^{* * *}$ & $25.55^{* * *}$ & $19.93^{* * *}$ & & & \\
\hline $\mathrm{R} 2$ & .32 & & .56 & & .53 & & .49 & \\
\hline
\end{tabular}

${ }^{*} p<.05 ;{ }^{* *} p<.01 ;{ }^{* * *} p<.001$.

\section{The structure of reversal motivational intelligences}

Factor analysis (principal component) was conducted for the 8 ratings of the self. The results evidenced one factor with an eigenvalue above 1 , accounting for 49.5 percent of the variance in the items (see Table 4).

Table 4. Factor analysis results.

\begin{tabular}{lc}
\hline Intelligence type & SC \\
\hline Telic & .73 \\
Paratelic & .74 \\
Conformist & .57 \\
Negativist & .63 \\
Autic mastery & .68 \\
Autic sympathy & .79 \\
Alloic mastery & .79 \\
Alloic sympathy & .67 \\
Eigenvalue & 3.96 \\
Variance & 49.50 \\
\hline
\end{tabular}

Note. SC $=$ Structure coefficients

\section{Beliefs about intelligence}

The results for the six items on intelligence and intelligence testing are shown in Table 5. They indicated that $42 \%$ of the respondents had ever taken an IQ test and also 59\% appeared to be suspicious concerning the validity of tests, They do not believe that, on average, men are more intelligent than women $(15 \%$ did, but $85 \%$ did not). Around a quarter of the respondents thought that intelligence is primarily inherited. In all $58 \%$ of the sample thought that IQ tests are useful in educational settings. Fifteen percent of these respondents argued that some races are more intelligent than others.

Finally, a series of chi-squares were performed on the six questions. Across gender, the analyses displayed significant differences only on question three (a greater number of men believed that they are on average more intelligent than women, $\left.\chi^{2}(1)=15.74, p<.001\right)$.

The six questions were regressed on the self-estimated overall $g$ score, and the totalled 8 . Both analyses showed no significance, $[F(6,164)=.51, p=.80]$, and $[F(6,163)=.96, p$ $=.46]$, respectively. 
Table 5. Beliefs about intelligence by sex (\%).

\begin{tabular}{|c|c|c|c|c|c|c|}
\hline & \multirow[t]{2}{*}{ Yes } & \multirow[t]{2}{*}{ No } & \multicolumn{2}{|c|}{ Males } & \multicolumn{2}{|c|}{ Females } \\
\hline & & & Yes & No & Yes & No \\
\hline 1. Have you ever taken an intelligence test? & 42.2 & 57.8 & 43.6 & 56.4 & 41.1 & 58.9 \\
\hline 2. Do you believe they measure intelligence well? & 40.7 & 59.3 & 44.2 & 55.8 & 37.9 & 62.1 \\
\hline 3. Do you believe males are on average more intelligent than females? & 15.0 & 85.0 & 26.9 & 73.1 & 5.3 & 94.7 \\
\hline 4. Do you believe intelligence is primarily inherited? & 26.9 & 73.1 & 25.0 & 75.0 & 28.4 & 71.6 \\
\hline 5. Do you believe IQ tests are useful in educational settings? & 57.2 & 42.8 & 56.4 & 43.6 & 57.9 & 42.1 \\
\hline 6. Do you believe some races are more intelligent than others? & 14.7 & 85.3 & 13.0 & 87.0 & 16.1 & 83.9 \\
\hline
\end{tabular}

\section{Discussion}

The current research partially replicated previous work, and also extended the literature by exploring self-estimates and estimates of partner and parents in a Brazilian student population within the framework of reversal theory (Apter, 2001).

Our first hypothesis was only partially supported. The hypothesis was supported for the overall intelligence, as men rated it higher than females and for alloic sympathy, as females rated alloic sympathy intelligence higher than males. However, no gender differences appeared in autic sympathy, as predicted. Furthermore, females rated higher alloic mastery intelligence than males. These findings question the idea that "lay conception of intelligence is men-normative" (Furnham \& Shagabutdinova, 2012, p. 450). In fact, Brazilian women scored higher than Brazilian men two self-estimates of reversal motivational intelligences focused on transactions and relationships with other people. Alloic mastery denotes intelligence as the ability to focus on the needs and inerst of others, while alloic sympathy denotes intelligence as the ability to feel affection toward other people.

Current findings also suggest that there were no gender differences in estimates of partner and parental intelligences. This is consistent with findings in Iran (Furnham, Shahidi, \& Baluch, 2002), but inconsistent with the extant literature (Furnham, 2001). A possible explanation for these results may be linked to changes, occurred in sex roles (Neto, Pinto, \& Furnham, 2012).

Respondents gave their fathers higher score than their mothers on global intelligence which is consistent with our second hypothesis and previous reported sex differences (Furnham \& Chamorro-Prezumic, 2005). However, participants gave their mothers higher score than their fathers on alloic sympathy.

The results indicated that participants thought they were brighter on reversal multiple intelligences than their parents, in agreement with our third hypothesis. These findings replicate the belief in the Flynn effect. They may also reflect the possible longer education of the respondents in this research than their parents, which may influence the estimated intelligence.

In general, telic and conformist reversal motivational intelligences were the strongest predictors of overall intelligence; however paratelic and negativistic intelligences were also good predictors for self and partner intelligence. Thus we found some discrepancies in connexion with the person being rated. This provides partial confirmation of the fourth hypothesis.

The factor analyses of the eight reversal motivational intelligences displayed one factor. This result supports our fifth hypothesis and it is in agreement with previous research about Apter's motivational intelligences (Neto et al., 2016; in press). Furnham (2005) also showed that all estimates loaded unifactorially in a research on business intelligence. Identical interpretation for the findings proposed by this scholar can also be utilized for current findings: "this may be interpreted as either evidence of a halo effect, an attribution error or a belief in a general intelligence factor" (Furnham, 2005, p. 100).

Last, besides the data for testing hypotheses in the current research, there were extra questions about experience and beliefs about intelligence and intelligence testing. The question that obtained more concordance (58\%) was that "IQ tests are useful in educational settings". This level of concordance may denote that the respondents were college students familiar with the use of IQ tests. There were only gender significant differences on the item about gender differences on IQ. Whereas the majority of both sexes believed that there were no gender differences, about a quarter of males claimed males were more intelligent than females. This result tends to be consonant with male hubris on the topic. However, these beliefs were unrelated to self-assessed intelligence.

The current research has some limitations. First, the sample consisted of college students in order to have a comparable sample to identical studies from others countries; however, the present sample is unrepresentative of the general population of Brazil. Second, given that the current research was correlational, the findings do not imply causation. Furthermore, it was assessed only self-estimated evaluations of intelligence and not psychometrically valid assessments of intelligences. Both lines of research can be compared in future work.

Researches on SEI have now been conducted in all continents. However, at the best of our knowledge, this is the first study from Brazil. The findings showed that there are universal patterns in gender differences of self-estimate of overall intelligence, as well as beliefs about generational differences. 


\section{References}

Apter, M. J. (2001). Motivational styles in everyday life: A guide to reversal theory. Washington, DC: American Psychological Association.

Byrd, M., \& Stacey, B. (1993). Bias in IQ perception. The Psychologist, 6, 16.

Chamorro-Premuzic, T. \& Furnham, A, \& Moutafi, T. (2004). The relationship between estimated and psychometric personality and intelligence scores. Journal of Research in Personality, 38, 505-513.

Chamorro-Premuzic, T., \& Furnham, A. (2006). Personality and selfassessed intelligence. Educational Research and Reviews, 1, 227-233.

Colom, R., Juan-Espinosa, M., Abal, F., Garcia, L. (2000). Negligible sex differences in general intelligence: Can gender and personality distort self-assessed intelligence? Intelligence, 28, 57-68.

Furnham, A. \& Akande, A. (2004). African parents' estimates of their own and their children's multiple intelligences. Current Psychology, 22, 281-294.

Furnham, A. (2001). Self-estimates of intelligence: Culture and gender differences in self and other estimates of general $(\mathrm{g})$ and multiple intelligences. Personality and Individual Differences, 31, 1381-1405.

Furnham, A. (2004). Are lay people lumpers or splitters? The factor structure of, and sex differences related to, self-rated and other-rated abilities. Learning and Individual Differences, 14, 153-168.

Furnham, A. (2005). Gender and personality differences in self and other ratings of business intelligence, 16, 91-103.

Furnham, A., \& Chamorro-Prezumic, T. (2005). Estimating one's own and one's relatives' multiple intelligences: A study from Argentina. The Spanish Journal of Psychology, 8,12-20.

Furnham, A., \& Shagabutdinova, K. (2012). Sex differences in estimating multiple intelligences in self and others. International Journal of Psychology, 47, 1-12.

Furnham, A., Fong, \& Martin, N. (1999). Sex and cross-cultural differences in the estimated multi-faceted intelligence quotient score for self, parents and siblings. Personality and Individual Differences, 26, 1025-1034.

Furnham, A., Rakow, T., \& Mak, T. (2002). The determinants of parents' beliefs about the intelligence of their children: A study from Hong Kong. International Journal of Psychology, 37, 343-352.

Furnham, A., Shahidi, S., \& Baluch, B. (2002). Sex and cultural differences in perception of estimated multiple intelligences for self and family: A British-Iranian comparison. Journal of Cross-Cultural Psychology, 33, 270285.

Furnham, A., Zhang, J., \& Chamorro-Prezumic, T. (2006). The relationship beween psychometric and self-estimated intelligence, creativity, personality, and academic achievement. Imagination, Cognition and Personality, 25, 119-145.

Gardner, H. (1999). Intelligence reframed. New York: Basic Books.

Giraudeau, C., Chasseigne, G., Apter, M. J., \& Mullet, E. (2007). Adults' lay views about intelligence: A Reversal theory approach. Personality and Individual Differences, 42, 169-179.
Kaufman, J. (2012). Self-estimates of general, crystallised, and fluid intelligences in an ethnically diverse population. Learning and Individual Differences, 22, 118-122.

Neto, F, \& Furnham, A. (2011). Sex differences in parents' estimations of their own and their children's multiple intelligences: A Portuguese replication. Spanish Journal of Psychology, 14, 99-110.

Neto, F. Pinto, M. C., \& Furnham, A. (2012). Sex and culture similarities and differences in long-term partner preferences. Journal of Relationships Research, 3, 57-66.

Neto, F., \& Furnham, A. (2006). Gender differences in self-rated and partner-rated multiple intelligences: A Portuguese replication. The Journal of Psychology, 140(6), 591-602

Neto, F., Furnham, A., \& Paz, R. (2007). Sex and culture differences in perceptions of estimated multiple intelligence for self and family: A Macanese-Portuguese comparison. International Journal of Psychology, 42(2), 124-133.

Neto, F., Mullet, \& Furnham, A. (2009). Sex differences in self-estimation of lay views about intelligence among adolescents. Personality and Individual Differences, 46, 541-546.

Neto, F., Mullet, E., \& Furnham, A. (2016). Self-estimated correlates of lay views about reversal multiple intelligences. Imagination, Cognition, and Personality, 35, 380-396.

Neto, F., Pinto, M. C., Mullet, E., \& Furnham, A. (in press). Estimates of lay views about reversal multiple intelligences for self and others: Sex and cross-cultural comparisons. International Journal of Psychology.

Neto, F., Ruiz, F., \& Furnham, A. (2008). Sex differences in self-estiamtion of multiple intelligences among Portuguese adolescents. Higher Abilit Studies, 19, 189-204.

Pérez, L., Gonzáles, \& Béltran, J. (2010). Parental estimates of their own and their relatives' intelligence: A Spanish replication. Learning and Individual Differences, 20, 669-676.

Rammstedt, B. \& Rammsayer, T. (2000). Sex differences in self-estimates of different aspects of intelligence. Personality and Individual Differences, 29, 869-880.

Sternberg, R.J. (1997). Successful intelligence. New York: Plume.

Swami, V., Furnham, A., \& Kannan, K. (2006). Estimating self, parental and partner multiple intelligences: A replication in Malaysia. The Journal of Social Psychology, 146, 645-655.

Szymanowicz, A., \& Furnham, A. (2011). Gender differences in selfestimates of general, mathematical, spatial, and verbal intelligence: Four meta-analyses. Learning and Individual Differences, 21, 493-504.

Szymanowicz, A., \& Furnham, A. (2013). Gender and gender role differences in self and other estimates of multiple intelligences. The Journal of Social Psychology, 153, 399-423.

Von Stumm, S., Chamorro-Premuzic, T., \& Furnham, A. (2009). Decomposing self-estimates of intelligence. British Journal of Psychology, 100, $429-442$ 